\title{
Status of Narcotic Drugs in Islamic Jurisprudence and Foundations of Islamic Laws
}

\author{
Kazem Mirzaei Nejad, Seyed Hossein Hashemi \\ Mofid University, Qom, Iran \\ Email: submit.hna4@gmail.com
}

How to cite this paper: Nejad, K. M., \& Hashemi, S. H. (2018). Status of Narcotic Drugs in Islamic Jurisprudence and Foundations of Islamic Laws. Beijing Law Review, 9, 401-424.

https://doi.org/10.4236/blr.2018.93025

Received: August 12, 2017

Accepted: September 10, 2018

Published: September 13, 2018

Copyright $\odot 2018$ by authors and Scientific Research Publishing Inc. This work is licensed under the Creative Commons Attribution International License (CC BY 4.0).

http://creativecommons.org/licenses/by/4.0/

c) (i) Open Access

\begin{abstract}
Narcotic drugs have been a problem for human communities for a long time. The problem has become even worse since its use has become broad and people can provide it manually and by industrial equipment. Regarding the depth of its teachings, Islam has focused its main attention on human and his/her well-being both in this and the other worlds. Islam has acknowledged and valued wisdom more than any other schools of thoughts and has never admitted inflicting harm on such a precious gold, including the harmful effects of the narcotic drugs that influences on the wisdom and psych of humans; therefore, Islam has seriously antagonized and prohibited this act and it has been certainly known as a forbidden act by the Islam. This article studied jurisprudential and legal foundations of prohibition of narcotic drugs, which are included in cases Islam has prohibited. All the following concepts approve the above claims and the authors of this article have studied them: Unjust enrichment, avoiding from unclearness and wickedness, abstaining from any evil acts and narcotic drugs use as a leader of all evil deeds, and destroying oneself. Furthermore, expanding, extending and presenting the foundation of the prohibition of narcotic drugs can help authorities with their mission in campaigning against such an evil phenomenon. The authorities will be able to prioritize fighting against drugs, and finally eradicate them with peace of mind and easefully with accessing to legitimate authorization and religious orders based on the prohibition of the narcotic drugs in Islam.
\end{abstract}

\section{Keywords}

Foundation of Prohibition of Narcotic Drugs, Legitimate Authorization, Unjust Enrichment, Prohibition of Inflicting Harm to Oneself and to Other People, Prohibition of Destroying Oneself 


\section{Introduction}

Studying narcotic drugs from legal and jurisprudential aspects regarding to new discussions about this issue is counted as the necessary arguments. Considering this necessity and basic questions posed in this field, the authors of the present article examined the above-mentioned foundations. We used the valid and original sources in Islamic jurisprudence and laws of narcotic drugs and invoking them in order to remove ambiguities in this issue. Doubtless, study in this field requires broad pondering and a new viewpoint to pave the way for further jurisprudential discussions for other researchers.

Basic questions posed in the present study are as follows: Are there any valid and referable jurisprudential and legal sources in Islam about prohibition of narcotic drugs? And how is the relation of these lows with existing international laws based? And whether we can rely to a present reliable solution to fight against narcotic drug usage?

Considering the above basic questions, the most important hypothesis is that Islam as a school of thought that its main goal is human salvation both in materialistic and spiritual aspects, has doubtlessly presented unavoidable and strong foundations for prohibition of narcotic drugs which by utilizing them; we can transmit a healthy and clean society to future generations.

On the other hand, explicit texts and statements existing in Islam are not in conflict with international laws, but they are in cooperation and coordination with them, but it should be noted, however, that some omissions in the international drug law are rooted in the goals of the beneficiary countries, so they are obstacles in enforcing serious prohibition for narcotic drug usage, but, Islamic jurisprudential and legal foundations have not such profiteering flexibilities.

\section{Concept of the Narcotic Drugs}

\subsection{Definitions for Narcotics}

There are various definitions for narcotics, either in terms of the word or term, we notice to the most important words and terms related to the narcotic drugs in this section:

\subsubsection{Lexical Definition}

Mokhader (Arabic word of the narcotic) have been derived from the word (al-Khadr), which means weakness, disability, also means coldness, generally it includes the meaning of fear, slowness, perplexing, indecisiveness, laziness, carelessness, and all these characters can be found in a drug addict and in all of these narcotic drugs, whether solid or liquid drugs (Moussa \& Saidi, 1989: p 482). Also, the word addiction literally means getting used to something in the Latin language (Arian Pour \& Manochehr, 1988).

\subsubsection{Terminology Definition}

The term of the drug narcotics can include the following definitions: 
1) In the sociological term, dependence to a substance or drug that is harmful physically or psychologically or socially is known as an addiction. Though it should be said that humans become addicted to a variety of things during their lives, including Internet, various drugs, eating fingernails, and so on (Abrakrambi, 1997).

In the new medicine, drug dependence is used instead of the addiction word, which has the same meaning but is more accurate and correct. The concept of this word is that one achieves relaxation and pleasure while receiving and taking this drug, but the failure to obtain it, leads to hangovers, physical pain and discomfort (Fedaei \& Sajadieh, 1986). In fact, this drug is the same narcotic drug, and according to the experts, the drug is "any raw or produced substance that contains irritating, or degrading elements used in the non-medical or non-industrial items, and the use of these substances leads to a person's addiction on a continuous basis and its losses appears in the community physically spiritually or socially" (Website of students and university graduates of Iranian Turkemans, 2007).

2) "Every kind of dependency is called addiction and the victim of any type of the dependency is an addicted person addiction" and the characteristic of this definition includes all addicting conditions.

\subsection{Narcotic Drugs in Jurisprudential Causes}

\section{A) Jurisprudential causes}

Sunni and Shi'a religion debate about narcotics in a number of jurisprudential causes that each one has presented independent opinions about prohibition, ta'zir (discretionary punishment awarded by the judge)..., which are briefly stated.

1) Tazirat (discretionary punishment awarded by the judge) and Hudood (Penance that is a punishment by a lash as ordained by the Islamic religion) causes

2) And whoever gives hashish to another person or befuddles him/her with something by eating or drinking and then takes his property away, he is punished and the property is returned to his/her owner according to what the Imam sees as good for ta'zir (discretionary punishment).

3) In the statement of ta'zir, you should know the sins that lead to the discretionary punishment of its performer are thirty-five types. Twenty-third: Someone who feeds hashish or anesthetic to other someone ${ }^{1}$.

4) Legislator distinguishes between the prohibitions that create the addiction among people and the prohibitions that do not create addiction, such as blood and the dead body, if a prohibition do not make an addiction, he/she will be sentenced by the religious punishment, but if he/she makes the addiction, they be sentenced by the religious punishment along with "Hadd" as a natural punishment (translator statement: Penance that is a punishment by a lash as or- 
dained by the Islamic religion) and hashish is included for this punishment ${ }^{2}$.

\subsection{Blood Money Causes}

"Mabnej" is someone who makes a person drink something that his/her mind is lost by drinking, which, in this case, this action is a crime that is created by the eater of the hashish, because it creates a defect in its wisdom and body and ta'zir is necessary for him/her; and if he/she has secretly taken something away and the theft has been proved with quorum, after the returning the property, his/her hand will be cut ${ }^{3}$.

\subsection{Forbidden Foods and Drinks Causes}

The deadly poison is forbidden, whether it is at a maximum or a minimum amount, but a minimum of it, is not forbidden to eat, if it is not lethal, such as eating opium and scammonia, and oil of colocynth and hemlock when they combine with other things, but a "Mesghal" (about five grams) of them are not allowed, and in general, any amount that is likely to be harmed is not permissible.

B) Any solid thing is forbidden that is harmful to the body or the wisdom, such as rock, soil, and poison, even it is a little (except for someone who is out of harms of it), and if it is liquid, it is also forbidden. An example of a harmful substance for wisdom is opium in a large quantity, and nutmeg, ambergris, saffron and hashish in a great amount ${ }^{5}$.

C) Any kind of alcoholic substance is forbidden, whether it is a solid or liquid thing, such as hashish, and what has been taken from wheat and the like; and except of the alcoholic liquid, other alcoholic substances are not unclean ${ }^{6}$.

D) Foods and drinks that can spoil the mind, are forbidden whether it is from liquids such as wine or solid, such as hashish and opium ${ }^{7}$.

\subsubsection{Unclean Causes}

1) And with the sentence "it must not harm the body or the wisdom", what is harmful to the body, such as toxins or "it harms to wisdom", such as opium and saffron, which are clear and its prohibition of eating is for their harm, not for uncleanness.

2) If the Hashish has been taken from the leaf of the hempseed creates a drunkenness, in terms of prohibition, it is like the wine, but it is not unclean.

\subsubsection{Prayer Causes}

Anyone whose wisdom loses himself by drinking alcoholic drink, hashish and

${ }^{2}$ Taghi-al-Din ibn Taymiyyah al-Hurani al-Fatwai al-Kabri, fourth volume, p. 26.

${ }^{3}$ Ali ibn Hamzeh al-Tusi, al-VasileEla Nil al-Fadhilah (Men al-Javama al-Fiqahiyeh) p. 424.

${ }^{4}$ Hassan ibn Yusuf ibn Ali al-Heli, the rules of the law, Vol. 2, p. 157.

${ }^{5} \mathrm{Abu}$ Bakr famous to-Al-Saied-al-Bakari, in margin of Eana-al-Talibin Alah Hal-al-Alfaz Fath-alMa'in, p. 355.

${ }^{6}$ Hassan ibn Yusuf ibn Ali al-Heliizah al-Favajid, Vol. 4, p. 159.

${ }^{7} \mathrm{Abu}$ Bakr famous to-Al-Saied-al-Bakari, in margin of Eana-al-Talibin Alah Hal-al-Alfaz Fathal-Ma'in, Vol. 1, p. 81. 
other things, and his/her prayers becomes lapse, it is imperative to recompense his/her prayers ${ }^{8}$.

1) But whoever loses his mind by drinking hashish, alcoholic drink, and sleep drugs or madding drugs, if he/she consumes it merely for treatment, he/she doesn't require to recompense the prayers".

2) In the case of a person who prayed and had hashish on his head, and he knew about it, he was asked: is his prayer correct? And he is required to recompense his prayer?

He replied: his prayer is correct and he does not require to recompense it, because the hashish is a clear drink ${ }^{10}$.

\subsubsection{Rent Causes}

When we can use something with a permissible profit and we give it to someone who uses it by an evil way, according to the vote of the Islamic jurists, its money gained is forbidden. Because of what we have mentioned from the arguments and the other, then, it is not permissible money that is gained from a prohibited profit, like the narcotic drugs ${ }^{11}$.

\subsubsection{Divorce Causes}

$\mathrm{He} / \mathrm{she}$ will not be divorced if his/her mind is lost by drinking hashish and sleep drug or maddened drug. Abu Hanife has also the same judge, and Shafi'i said: "If his/her drinking is for treatment and his/her wisdom goes away, his/her divorce will not be done. But if her/his drinking is due to the entertainment and enjoyment and without any logical reasons, he/she is divorced and the need for reasonable divorce, she will be divorced. Our reason was said was said in the first problem. Which is their consensus and news; as well as the principle of the survival is the marriage and the divorce needs the reason and there is no reason at the religious laws for doing this type of divorce ${ }^{12}$.

\subsubsection{Sale Causes}

1) Poisons, such as hashish and such plants, its sale will be permitted if it is useful, otherwise it is not permissible ${ }^{13}$.

2) One of the conditions of the sale is the benefit, that is, it should have a religious benefit, and the sale of poison will be prohibited, if it is a deadly act, whether it is a little or a lot, but if its minimum usage has benefits such as the opium, its sale will be correct (Mohammad al-Zahiri \& Al-Ghamrawi, 1988: p. 534).

\section{Background of Narcotic Drugs}

Narcotic drugs are nasty and ominous phenomena that have led many people to

\footnotetext{
${ }^{8} \mathrm{Abu}$ Ja'far Muhammad al-Hassan ibn Ali al-Tusi (Sheikh Tusi) al-Mubsut, Vol. 1, p. 128.

${ }^{9}$ The same reference, c 5 p. 524 .

${ }^{10}$ Shams-al-din Mohammad Hamza al-Ramli, Fatava al-Ramli Bahamesh and Fatavaibn Hajar, vol. 1, p. 174.

${ }^{11}$ Abdulrahman -al-Jaziri, Alfagheh Ala al-Mazaheb-e-Arbaea, vol. 5, p. 41.

${ }^{12} \mathrm{Abu}$ Ja'far Mohammad ibn al-Hasanibn Ali al-Tusi, al-Khalaf, Vol. 2, p. 454.

${ }^{13}$ Hassan ibn Yusuf bin Ali al-Heli, Ghavaed-al-Ahkam, Vol. 1, p. 120.
} 
misery, calamity and wretchedness. They have made irreparable harms generally in Muslim countries and specifically our Islamic country (Abo Albarakat, 1985). As a proclaimer of human salvation in both worlds, Islam has always brought admirable methods of life for human being. It has also restrained humankind from deviation and refraction; especially what brings about dementia such as narcotic drugs, alcoholic liquors and has issued serious warned about them (Ibn Baraj, 1985).

Other reasons behind the increasing expansion of this phenomenon among Muslim countries include interfering political purposes to vitiate real face of Islam and distorting Islamic teachings by foreign countries. We also refer to gaining economic aims to illegitimate and excessive wealth. This has made death dealers (an idiomatic expression in Persian for drug smugglers) produce industrial production and alter the chemical formula in narcotic drugs. The above process has paved the profiteering people to reach different kinds of such materials with various and harmful effects (Bojnourdi Mousavi, 2000). The authors of the present article intend to study more about the teachings and foundations taught by Islam to recognize and introduce the status of Islam regarding narcotic drugs.

Sumerian people have dealt with cultivating poppy and utilized its pharmaceutical advantages. They called it a mirthful plant. This phenomenon has also an old history in Europe (Oakeley \& Wayburn, 1972). Thousands years ago, aboriginal people of one of the hot and dry countries of the Middle East discovered a one-year plant that produced a kind of essence during 7 - 9 days that can relieve the pain. Poppy has firstly planted in Egypt and known as Thebaica. The above word has originated from the word "Tabas"; a city in Ancient Egypt where people had planted poppy. Ebers Papyrus remained from 1500 BC has referred to a method to quiet down children (Ibid.).

We have observed some references to poppy in some works of classical literature such as Virgil and Ovid, and goddess of sleep of Ancient Greece people called the Hypnos similar the Roman sleep goddess, called the Summons, appears with a branch of poppy in hand and decorated herself with it (Ibid.).

The opium had been very important in Ancient Greece and it considered as a medicine for all pains. It is resistant against poison, biting, toxin, and treats chronic headache, vomiting, vertigo, deafness, asthma, colic, chlorosis, solidity of spleen, kidney stone, grievances about urinary system, fevers, leprosy, problems related to women, melancholia, plague (Ibid.). People imported poppy seeds to Iran and then exported it to China (Karim Pour, 1985). It seems that the origin of the poppy is Mediterranean shores where it grew naturally. Some of the old sources, including Nasser Khosrou's travel account (one of his books known in Persian as Safarname) have introduced Egypt as the origin of poppy. Nevertheless, new researches have indicated that mysteries of producing and consuming opium had entered into Eastern Europe in Balkans Region and around the Black Sea and then pushed its way towards the west (Isfahani, 1984). 
Archaeologists have gotten access to historical evidence indicating that planting poppy referred back to 15,000 years ago, but, remained historical records have not proved that ancient people had been aware of medicinal advantages and features of opium. Perhaps, they used it traditionally and without any knowledge of its applicability. In the Roman Empire, people have probably been utilizing opium in religious ceremonies and they might have used it for symbolization of the death process and reincarnation. Even older records indicate that ancient people may have believed that poppy could have been mirthfully, although, there is no evidence indicating people of that era had used it for recreation (Miller, 2014).

\section{Background of Narcotic Drugs in Iran}

People had brought poppy seeds from Egypt to Greece and circulated it. Arabian merchants imported poppy seeds as a medicine to Iran in 5th century B.C. and had brought it to China from Iran. Researchers reported that the Portuguese had imported opium in India. The British had played an important role in the onset of opium addiction in different countries when they started imperialism (Ibn Manzoor, 1986). Some researchers believe that entering opium into Iran was an outcome of the Arab conquest of Iran or Genghis Khan's aggression to Iran and others consider it for Teymur's attack on Iran.

Some historical records show that consumption of opium in Iran as a pharmaceutical reliever was the outcome of IbnSina and Zakariya Razi's researches. They were the first two physicians who discovered the features of opium. Another group of researchers believes that opium is the result of the Nader Shah's military expedition to India. Doubtless, consumption of opium was usual in the Safavid era to adjust the mindset of the great men of the imperial court. Shah Tahmasp had seriously regarded prevention of consuming opium and declared the order to destroy existing narcotic drugs in the imperial court in the 10th century A. H. (i.e. Anno Hejirae) ${ }^{14}$. Consumption of this material has been broadly used in Shah Abbas' era. It is said that poppy syrup was so prevalent that Shah Abbas has found out the necessity of campaigning against it. Hence, he had issued some severe orders and guidelines to prevent people from using it and to terminate opium consumption.

European imperialists have followed their aims starting with two measures: First, they intended to cause disunion between Islamic societies. Moreover, they wanted to weaken and terminate the strength of Islam through maximizing spite and disagreements. Second, they wished to put opium consumption in circulation through their direct and indirect agents and assistants.

In general, opium smoking started in Naser al-Din Shah Qajar era. As the evidences indicate, people had tentatively planted poppy around the city of Tehran in Amir Kabir era.

Therefore, we can infer that the background of planting, distributing and

${ }^{14}$ Ebne Babvye, Bita publication. 
consuming narcotic drugs referred back to many years ago. People had produced and consumed narcotic drugs, mainly opium and poppy in different regions of Iran. Iranian government undertook trade monopoly of opium within the country in the Reza Khan's era. The problem of narcotic drugs gradually formed due to the following reasons: increasing population; changing economic, cultural and social structures of Iran during 1950s to 1970s; upgrading incomes; entering manifestations of Western culture; evacuating villages; expanding urbanization and marginalization and other factors. The reason was that limited consumption and mainly recreational use and distribution under the supervision or at least with the government's knowledge changed into an increasing addiction of the youth to different kinds of narcotic drugs especially heroin. Moreover, it led to the formation of bands that distributed narcotic drugs and a profiteering trade. Pahlavi regime started some measures to limit planting poppy and to campaign against distribution and consumption of narcotic drugs from the late 1960s and the above measures have continued with ups and downs until 1979. Nevertheless, regime's controlling measures did not have so much preventive effects. Some factors including, the followings were barricaded to take principal and serious measures to campaign against this increasing phenomenon: lack of serious wish in Pahlavi statesmen; their use and smuggling narcotic drugs, even in international level, and more important than these cases were cultural, social and economic policies of the regime to fight against this expended phenomena (Ansari, 1988: p. 78).

There are no precise statistics about the amount of production, distribution, the way of campaigning against smuggling and consuming narcotic drugs during the previous years of Islamic revolution in Iran.

The important point is that narcotic drugs had not been so much prevalent, expansion and seriousness before the Islamic revolution. Hence, political leaders and people of the Iranian society had regarded the issue of narcotic drugs not only as a security threat but also as a social harm and a kind of deviation. Doubtless, foundations of Pahlavi's regime have verified such a viewpoint. Despite of using Iran as a transit path from Afghanistan and Pakistan to Europe, there was not such an expanded European market for narcotic drug. In addition, the two above countries did not produce such a large amount of narcotic drugs compared to now. Hence, less security problems were created (Hagh Panah, 1998: p. 18).

\section{Current Status of Narcotic Drugs in Iran}

Experts of the addiction area say that one person's consumption of methamphetamine is at least $0.5 \mathrm{~g}$ per day. Regarding to addiction of 343,200 persons to methamphetamine in Iran, at least more than 62 tons of methamphetamine are used in this country. According to Fars news agency, based on statistics declared by Iran Drug Control Headquarters and based on the study of prevalence of drugs in 2011, there are 1,325,000 persons addicted to narcotic drugs. Hamid 
Sarami, director general of Research and the Training Office of Iran Drug Control Headquarters divided consumers of narcotic drugs when speaking with a Fars news reporter. He stated that $55 \%$ of consumers of narcotic drugs use opium, $26 \%$ of them use methamphetamine, 16\% consume Afghani crack, $8 \%$ use heroin, $6 \%$ use poppy and $3 \%$ consume MDMA (XTC). Sarami also emphasized that the total of the above percent may be more than $100 \%$ because one addicted person may consume several kinds of narcotic drugs altogether.

With regard to statistics presented by Iranian authorities, we can find out with a rule of thumb that 726,000 persons consume opium, 343,200 persons use methamphetamine, 211,200 persons consume crack, 105,600 persons use heroin, 79,200 persons utilize poppy, and 39,600 persons use MDMA (XTC). The total amount of the above persons is slightly higher than the total amount of addicted persons because one addict may use more than one addicted material. Here a question is posed: How much do these addicts consume drugs every day? In response to the above question, Saeed Sefatian, a psychologist of addiction, believe that each addicted person consumes in average $1.5 \mathrm{~g}$ of opium per day, and the consume average of heroin and methamphetamine is $0.5 \mathrm{~g}$. He added that if we multiply $1.5 \mathrm{~g}$ by the numbers of year's days, we could observe that an addicted person consumes $548 \mathrm{~g}$ of opium per year. According to presented statistics by Sefatian, we can conclude that about $397,485 \mathrm{~kg}$ of opium is used per year in Iran and daily consumption of opium is more than one tone in Iran. We can calculate with a rule of thumb that $62,634 \mathrm{~kg}$ of methamphetamine is used per year in Iran. Having the existing statistics, we should state that at least 460 tons of opium and methamphetamine is used per year in Iran. However, based on what the deputy of director general of Research and the Training Office of Iran's Drug Control Headquarters has declared, the whole discovered narcotic drugs have been 555 tons that include all kinds of narcotic materials in $2014^{15}$.

\section{Narcotic Drugs in Religious Sources}

\subsection{Holly Qur'an}

The first reason of four reasons used in Islamic jurisprudence is the Holly Qur'an and we review a reason of the God statement that it declares any type of the narcotic drugs have been prohibited.

\subsubsection{Unjust Enrichment Equals to Committing Suicide}

One of the Quranic verses that proves the prohibition of narcotic drugs is Verse No. 29 of Sürat al-Nisā' (women) that is known as the "unjust enrichment Verse" and the message of the above Verse is that every transaction originated in immorality includes the transaction of narcotic drugs and is considered as "unjust enrichment" and is counted as the suicide; so it is prohibited.

Sūrat al-Nisā [verse 29]: "O you who have believed, do not consume one another's wealth unjustly, but only [in lawful] business by mutual consent. And

\footnotetext{
${ }^{15}$ http://alef.ir/vdchiqnim23n-6d.tft2.html?267825, Date: 23/01/2017.
} 
do not kill yourselves [or one another]. Indeed, Allah is with you ever Merciful."

Ayatollah Makarem Shirazi has interpreted the above Verse, that all of the following cases are included in the general rule: every kind of trespass, fraud, deception, and usury trades; dealings whose amounts are ambiguous; selling and buying goods that do not result in logical and rational benefit, and selling and buying means of corruption and committing sin. If in a number of interprets, the useless word is interpreted as gambling, usury and the like of them, in fact, they are some obvious manifestations of this word, and it does not limit to them (Makarem Shirazi, 2007).

The great jurisprudent, late Mohammad Hassan Najafi, invoked to the above Verse and states: "The above Verse includes preserving life, removing hardship and difficulty, preventing killing and demolishing. Two narrations recited by Ibn Salem and Davood Raghi approve this claim. In other words, preserving soul, removing hardship and difficulty and providing well-being and avoiding murder is obligatory (Najafi, 2000).

Sheikh Alish' religious statement, a scholar of Maliki Sect, holds: "continuous consumption of narcotic drugs causes a heat in the body and it causes a hard and lethal illness, Hence, it includes as God statement that do not to kill each other"16.

Concepts of the two above Verses oblige human beings to preserve good health. They also oblige humankind, not to put soul in danger or risks leading to murder unless another important interest exists such as jihad for the sake of God and due to the narcotic drugs cause harm, damage and endanger health and this subject has medically proved, so, its consumption is prohibited.

\subsubsection{Spirit of Islam's Invitation: Intending towards Good and Avoiding of Evil}

Islam is a religion that invites people to virtue and has no conformity with corruption. Based on this ideology, Islam has prohibited all actions and behaviors that lead to impurity and wicked acts. The following Verse verifies this claim:

Those who follow the Messenger, the unlettered prophet, whom they find written in what they have of the Torah and the Gospel, who enjoins upon them what is right and forbids them what is wrong and makes lawful for them the good things and prohibits for them the evil and relieves them of their burden and the shackles which were upon them. So they who have believed in him, honored him, supported him and followed the light which was sent down with him-it is those who will be the successful ${ }^{17}$.

Jurisconsults and scholars infer from the above Verse that God's invitation is coordinated with common sense. He will make good things and what common sense admires lawful and prohibits all that is foul. He is not like those who claim to have a mission, but enslave mass people and exploit them. He does not enslave them; rather, he relieves them of their burdens and of the shackles that ${ }^{16}$ The Institute of Encyclopedia of Islamic Law on the religion of Ahl_al-Bayt (as), Qom-Iran, 1st, $1421 \mathrm{AH}$.

${ }^{17} \mathrm{Al}-\mathrm{A}$ 'raf-157. 
weigh upon them. Now a question is posed here: Can a reasonable person say that narcotic drugs are included in good and permissible things? Surely, narcotic drugs are included in the foul and are prohibited. The reason is that harms originate from them are obvious to all people and keep human beings in shackles of inferiority (Makarem Shirazi, 2007: p. 470).

\subsubsection{Narcotic Drugs; Evil Act}

The spirit of Islamic invitation considers the fortification of reason as the core of human upgrading. Accordingly, Islam considers every act that causes harm to this precious gold as an evil act and not admirable, so prohibits it. It also declares its dissatisfaction about tendency to such kinds of behaviors. The following Verse verifies this viewpoint:

"O you who have believed, indeed, intoxicants, gambling, [sacrificing on] stone alters [to other than Allah], and divining arrows are but defilement from the work of Satan, so avoid it that you may be successful-Satan only wants to cause between you animosity and hatred through intoxicants and gambling and to avert you from the remembrance of Allah and from prayer. So will you not desist?"18

Muslims' familiarity with Islamic orders and their intellectual readiness for eradication of this entered the big social mischief into the profundities of their entity led to the final order that was sent with complete explicitness and clear-cut expression so that even excuse seekers could not object to it. This is the Verse that is under discussion.

\subsection{Narrations}

The second reason to which jurisconsults resort is the collection of narrations recited from infallible Imams. They use them alongside with Quranic verses to deduce religious orders. As the holy Quran has prohibited narcotic drugs and regarded them as inadmissible, narrations have verified such prohibition. Narcotic drugs were not so broad during the period of the Prophet and Imams. Nevertheless, there are many narrations recited by the Prophet and infallible Imams. Regarding necessities of time and place and increase in harms caused by consumption of narcotic drugs, they came as accessions. Islamic Imams have predicted this issue.

\subsubsection{First Group of the Degree Narrations}

A Shi'ite jurisconsult, Mirza Hossain Nouri has written some narrations in a book entitled: "Mostadrek Al-vasael" that verify the above claim ${ }^{19}$. The authors of the present research refer to some of them as follows:

1) Prophet's family members reported that Prophet stating: "Time will come for these believers when they consume hashish, I will be disgusted with them

\footnotetext{
${ }^{18} \mathrm{Ma}$ 'idah/90 and 91 (Verses).

${ }^{19}$ For further reading, see: Noori Mirza Hassan, Mostadrek Al-vasael, First Edition, 18th Edition, Beirut, Al-Beit Institute, Vol. 17, 1408 AH.
} 
and they will be disgusted with me.

2) You can say hello to the Jewish and Christians, but do not say hello to a person who consumes hashish.

3) A person who reduces sin of hashish consumption is infidel.

4) A person who consumes hashish, he/she is like the ones who destroy Kaaba 70 times, and murders 70 archangels and 70 messengers, set 70 Quran on fire, throw 70 stones towards God. Such a person is even worse than a drunkard, a usurer, a person who commits adultery, and they are seriously far away from God's blessing (Noori, 1987: p. 78).

\subsubsection{Second Group of the Degree Narrations}

Motaghi Hendy, one of the other skillful jurisconsults has presented two narrations in his valuable book entitled "Kanz Al-omal" that reflects Imams' predictions:

1) Prophet's family members reported that Prophet stating: "Time will come for these believers when they consume hashish, I disgust them and they disgust me."

2) Be aware that every trick and every kind of narcotic drug is prohibited. In addition, everything that is intoxicating, even its small amount, is prohibited, and also everything that bewilders wisdom (Anas Ibn, 1998: p. 92).

3) Enss Ibn Hazifeh said that he wrote a letter to the Prophet and reporting after prohibition of wine, people started drinking other liquids that is produced like the wine such as date, raisins that are the intoxicant. They produced them in some pots from marrow that besmeared with crude oil and plant containers. Then they pour them in goatskin and tied it and gave it to the other people. This news came to the Prophet, he rose among people and stated: "Those who will go to the hell are doing this action they should be aware that every intoxicating and every inebriating and narcotic substance is prohibited. What causes intoxication in large amount, its small amount is also prohibited. What causes drowsiness to reason is prohibited (Ahmadi, 1998: p. 584).

\subsubsection{Third Group of Degree Narrations}

A valuable book entitled "Tohaf Al-oghol" written by the honorable scholar Hassan Ibn Ali known as Ibn Shabe Harani, another book entitled "Vasael Al-Shieh" written by Sheikh Horr Ameli, Mohammad Ibn Hassan and many other jurisprudential books have recited this narration:

From Imam Sadegh (PBUH) is reported that what is harmful to human including poisoning deadly vegetables, the oleander and the like of these are prohibited from eating (Ibn Shubeh, 1984: p. 45).

\subsubsection{Fourth Group of Degree Narrations}

1) Imam Reza's narration

In a long narration, Imam Reza (PBUH) mentioned the philosophy of what is prohibited and what is permissible of all eatable things. He then refereed to every kind of eatable and drinkable things and stated: 
Be aware that God blesses you, God did not permit any drinkable except there was a benefit in it. In addition, He did not declare anything prohibited except there is a loss and corruption in it. Hence, everything that has the strength of body and physic is permitted and everything harmful that demolishes energy and power of the body or is lethal is prohibited such as kinds of poisons, meant of a dead animal and blood.

In the above narration, although at first eating and drinking are posed, the concept of all things is a general rule of prohibition for some of the other things.

2) Sheikh Sadogh's narration

This narration recited from infallible Imam (PBUH) and it states that when the fast harms on human, breaking a fast is obligatory. This indicates that inflicting the body is prohibited, otherwise, breaking a fast would not be obligatory. When the fasting that is so important in Islam, it will be prohibited, if it is harmful for the body, we can conclude that narcotic drugs that destroy the foundation of body and soul are primarily prohibited (HorAmeli, 1988: p. 219).

3) TalheIbn Zeid narration

Pay attention a person who asks you protection like yourself and avoid harming him just as you don't like to be harassed.

Regarding the two above narrations, we can find out that everything would be prohibited, if it harms the human even fasting. Hence, narcotic drugs are prohibited since they harms human from every aspect (Koleini, 1986: p. 292).

\subsection{The Place of the Narcotic Drugs in the Behavioral Style of the Wise People}

The behavioral style of the wise people is the third reason that a juris consult uses to issue a religious rule in Shi'i school of thought that it should be deeply conceptualized and then used in the narcotic drug prohibition.

\subsubsection{Definition of the Behavioral Style of the Wise}

Scholars of Principles of Shi'i jurisprudence have used expressions such as usage of the wise, customary of the wise, practice of the wise, intellectual practice, and method of the wise people, the foundation of the custom, behavior and practice of the wise in the last two centuries. They are in fact the common law or a branch of it (Jafari \& Mohammad, 1991: p. 217) and it has been defined as:

"The behavioral style of the wise is the continuity of common practice and attitude of the majority of the wise in their conversations and interactions and other social relations without regarding their religion and nationality" (Ibid.). In other words, the purpose of the behavioral style of the wise is the continuity of the practice of the wise; it is a behavior and action that are always performed in every place (Golbaghi Masoleh, 1999, p. 173). The behavioral style of the wise can be discussed in two categories: "the behavioral style of the wise" as in specific meaning that is in contrast with "the legitimate behavioral style of the wise" and "the behavioral style of the wise" as in the common meaning that includes the "legitimate behavioral style of the wise." 


\subsubsection{The Elements Involved in Forming the Behavioral Style of the Wise}

A behavior should have specific elements for having the rationalistic feature and it should be formed by the components of the rationalistic action, these components include:

1) A specific action (such as helping a blind person to cross a street);

2) Repetition of an action;

3) Pervasive; namely, it should be so repetitive that it changes into a common and prevalent action so that it includes all cases in people's actions;

4) An action should be good; weather it is voluntary and/or innate (Ibid).

As an instance, based on innate intellectual standards and tangible observations, some of the wise such as promisor physicians believe that intoxicating alcohol puts the human out of a normal situation. They discover that these substances keep the human in a state of drunkenness that it is likely he/she performs every dangerous and disgracing behavior (Shariati, 2006: p. 72).

Some of analyzers claim that the behavioral style of the wise is valid when infallible Imam verifies it. Nevertheless, there were not narcotic drugs in the modern form at that time, but we should remember that infallible imams have not verified the harm and damage resulted from the consumption of such drugs at all. Hence, we can find out their disapproval of narcotic drugs.

Therefore, we should say that the behavioral style of the wise during the history was based on avoiding and abstaining narcotic drugs. Due to the issue that one of the difficulties and concerns of the modern world is narcotic drugs and due to its internationality, psychological, financial, personality consequences and its influence on the families and communities, has attracted the attention of different groups of people, state and military authorities and international organizations and they have started taking broad measures to campaign against this wicked phenomenon. Among all these actions, many governmental and Non-governmental Organizations (NGOs) have taken some steps in this regard. The publications and Islamic Republic of Iran Broadcasting (IRIB), some of great scientists and religious leaders have discussed about harms and damages resulted by narcotic drugs. Persons addicted to narcotic drugs are the most detested persons in the Islamic Republic of Iran, and even their wives, children, parents and mothers suffer from them. The issue is so important that all executive organizations and authorities have been mobilized by all capabilities in order the health of the society. All countries of the world intend to prevent and campaign against this wicked problem and there is a consensus about narcotic drugs, because this campaign seems a rationalistic issue.

\subsection{The Judgments of the Contemporary Religious Leaders about the Narcotic Drugs}

In this chapter, we address to a number of religious judgments of the contemporary religious leaders about the narcotic drugs: 


\subsubsection{Ayatollah Makarem Shirazi}

1) Consumption of narcotic drugs is one of the prohibited cases that certain religious evidence indicate to its prohibition. All Muslims are obliged to avoid abstaining from them and prohibit their children and relatives from consuming such substances. Every person who assists to plant, provide, transfer and distribute these substances are subject to God's punishments. Every income gained from them is prohibited and illegitimate (Makarem Shirazi, Question No. 497).

2) "Narcotic drugs in any form and feature is prohibited and professions and dealings of all persons who are responsible for distribution and prevalence by any method are prohibited and illegitimate. Planting narcotic drugs is now prohibited and duties and jobs of those who are in charge of such professions are prohibited. In fact, this is like what Prophet stated about wine and indicated that God damned ten tribes related to drinking wine. That is to say, God has made such people far away from His blessing. Narcotic drugs are the same and even worse than this. The serious Verses would certainly be sent about narcotic drugs, if there were such a situation in the early ages of Islam. Nevertheless, it is clear from principles of Islamic jurisprudence that such a ruling would be certain. Consumption of narcotic drugs is included in certainly prohibited cases. Materialistic, moral, social and economic harms and damages arisen from this issue are obvious for everyone. The worst of all is that narcotic drugs changes into one of the harmful means of exploitation to attain income."

3) Consumption of narcotic drugs and every activity related to them is a mortal sin and it is prohibited. Usage of mirthful pills that cause hallucination and when cause considerable harm or some corruption is not permitted.

\subsubsection{The Late Ayatollah Borojerdi}

"I have always written that Muslims and all the wise people are required to save themselves from such lethal poison."

Besides, he stated in other sources: "Everything that destroys wisdom is prohibited in Islam."

\subsubsection{Ayatollah Fazel Lankarani}

"Consumption of narcotic drugs is not at all permissible due to the following reasons: they inflict to body and soul of human greatly and derange all reasonable and natural, personal and social affairs of people; they prevent people from doing their obligatory duties and religious affairs; they have also other mischief."

\subsubsection{Ayatollah Safi Gulpaigani}

"Loss of such harmful poisons and seditious dangers for religion, faith, honor, independence, health of soul and body and all status of society is quite clear. Every act, dealing and transformation that destroy the security of Islamic society and causes some risks for people to get addicted to such poisons is strongly prohibited. Preventing the sins and prevent such a thing is a direct obligation of government and all people oblige to do the same according to religious standards. All people should coordinately prevent this sin and other sins that cause 
corruption and wickedness in moral and ethics in Islamic society."

\section{The Status of the Narcotic Drugs in the Law}

In this section, we will discuss the status of the narcotic drugs in the law, and we will present it in two separate parts, before the Islamic Revolution of Iran and after the revolution. Because the process of combating the phenomenon of narcotic drugs originates before the revolution, and there were also approved laws at the time that we only review these articles in the thesis.

\subsection{Approved Laws before the Revolution}

As mentioned above, in addition to the verses and narrations and the jurisprudential approaches that emphasize on the prohibition of the narcotic drugs, there are also laws and decrees for this issue that related to before and after the Islamic Revolution of Iran which are listed below:

1) First law of the narcotic drug was defined 98 years ago (1919) under the title of the Opium Containment Act. During this period, more than 70 laws, regulations, decrees and bills have been approved about various issues of narcotic drugs have been approved.

2) Approval of the Opium Containment Act in the National Assembly, after the Iranian Constitutional Revolution victory (1905), and the General Penal Code law of the notorious use of oppression, opium, opium, morphine, bang and hemp juice, adopted February 7, 1925

3) Punishment Law of the smugglers of opium, adopted on December 3, 1929

4) The Law on the Prevention of Smuggling of Opium, adopted on December 3, 1929

5) Penal Code of the perpetrators of smuggling, adopted on March 29, 1933

6) To give Coupon for opium consumption in Iran after Reza Shah's banishment in 1941

7) Approval of the establishment of the Commission on Combating Opium, adopted July 23, 1946

8) Approval of the narcotic drugs, April 19, 1947

9) Corrective Amendment to Article 275 of the General Penal Code, adopted July 7, 1949

10) The Law on the Amendment to the Law on the Prohibition of the Cultivation and Use of Opium, adopted on April 19, 1959

11) The Budget Commission's decision on how to pay tenth of the fine of 10 fines as a prepayment to narcotics explorers up to a maximum of Five tenth, adopted on 1959

12) Amendment of the Law on Prohibition of Poppy cultivation adopted in 1963

13) The law on Payment for exploring narcotic drugs, approved March 27, 1963

14) The law of aggravating the punishment of the main perpetrators of crimes 
under The Law on the Amendment to the Law of prohibiting cultivation and abolishing permission to prosecute and execute the punishment of other perpetrators of these crimes approved on June 31, 1969

15) Executive regulation of Article 3 of the opium Containment and Export Act, adopted on September 20, 1968 in the Committees of Judiciary, Land Reforms and public health

16) Executive regulations on the subject of Articles 4, 5, 6 and 7 of the opium Containment Cultivation of the poppy and the export of opium, adopted on September 20, 1969 in the Committees of Judiciary, Land Reforms and public health

17) The law of Transferred Lands Extradition from Addicted Farmers, adopted January 9, 1968

18) The Law on Opium Trafficking and Assistance to the Treatment of Addicts, approved on July 7, 1970

19) The poppy Containment Permission cultivation and opium exporting, approved on August 31, 1970

20) The Executive Regulation of Note 3 of the Law on Opium Transaction and Assistance to the Treatment of Addicts, approved 3 December 1970

21) Permission of the Poppy Cultivation to agricultural companies, and rural-agriculture cooperatives of the six approved provinces, February 3, 1970

22) Forgiveness Law of a Part of Cash Penalties of the condemned prisoners of the Law on Prohibition of Poppy Cultivation, dated March 25, 1970

23) The Psychotropic Substances Act, approved April 13, 1966

24) Approval of 52 laws and regulations by the governments in the field of combating the narcotic drugs 1978-2007 (Ghangi, 1997: p. 335)

\subsection{Laws and Decrees after the Revolution}

1) Prohibition of poppy cultivation (1978) according to the Islamic Revolutionary Council

2) The Decree of the Presidents of the Islamic Republic of Iran on the Elimination of the narcotic drugs, approved on May 18, 1978

3) Legislative Bill on the aggravating of the Sentences of Perpetrators of Narcotics Crimes and the Therapeutic Measures for the Treatment and Employment of Addicts, approved on June 9, 1980

4) The Law on the Dissolution of the Opium Transactions organization, dated December 3, 1981

5) The Law on the accession of a Note to the Article 1 of the Law on the Extension of the Punishment of the Perpetrators of Narcotic drugs Crimes and of the Provisional and Therapeutic Measures for the Treatment and Employment of Addicts by the Revolutionary Council, adopted on June 19, 1980

6) The Law on the Issuance of Competence for Prosecutors and Revolutionary Courts, approved on April 11, 1983

7) The Law on the Amendment of Article 19 of the Penal Code of the Smugglers, approved on 1933 and the subsequent amendments 
8) Approval of the Anti-Narcotic drug Act of the Expediency Discernment Council, approved on November 3, 1988

9) Executive Regulation of the Anti-Narcotic drug Act of the Expediency Discernment Council, February 2, 1988

10) Act of the Expediency Discernment Council about of the stopped death sentences for narcotic drugs ratified on July 13, 1988

11) Amendment of the Anti-Narcotics Act in the Expediency Discernment Council adopted on August 10, 1989

12) Amendment of Article 28 of the Anti-Narcotics Act $(30 / 08 / 1986)$ of the Expediency Discernment Council approved on December 21, 1986

13) The Executive Regulation of the Anti-Narcotic drugs Act, adopted on 22/01/1989 by the Prime Minister, includes 35 articles and 5 Notes

14) The Law of Accession to the United Nations Convention against Illicit Traffic of Narcotic Drugs and Psychotropic Drugs, adopted December 17, 1991

15) United Nations Convention against Illicit Traffic in Narcotic Drugs and Psychotropic drugs adopted by the General Assembly on December 20, 1988 at the Sixth General Meeting of the Signatories to this Convention

16) Information Exchange Resolution, United Nations Summit for the Adoption of a Convention against Narcotic Drugs and Psychotropic Drugs Trafficking, adopted on December 3, 1991

17) Resolution on the Temporary Implementation of the United Nations Convention against Illicit Traffic in Narcotic and Psychotropic Drugs, adopted on December 3, 1991

18) The Law on the Amendment of Article 33 of the Anti-Narcotic drugs Law, approved on 08/09/1991 by the Expediency Discernment Council approved on October 2, 1991

19) The Law on Amendment of the Anti-Narcotic drugs Law and the accession of some articles to it, approved by the Expediency Discernment Council, approved in 2000, includes 42 articles and 24 notes, which are currently important in preventing the use, distribution, cultivation and... of the narcotic drugs in the country, that in Article 1, acts such as cultivating poppy, cocaine, hemp, importing, sending, producing, storing, transporting, purchasing, distributing, concealing, transiting, supplying and selling, setting up or managing the place for drug use in any form and way, etc., and the perpetrators are punished for the charges prescribed in this law.

\section{The Status of the Narcotic Drugs of the Approved Law in 1997}

The laws passed in 1997 and approved their last amendment in 2010 by the Expediency Discernment Council, these laws have considered that dealing with the narcotic drugs as a crime in their various cases, and include the necessary punishment for the perpetrators.

The text of this law with the latest amendment (approved by the Expediency Discernment Council (2010) is as follows: 
The Law of Anti-Narcotic drugs' Law with Amendments and Annexations

Article 1-The following acts are crime and the perpetrator will commit the prescribed sentences in this law:

1) Cultivation of poppy and cocaine, and the cultivation of cannabis for the production of the narcotic drugs or non-pharmaceutical industrial psychotropic drugs,

2) Importing, exporting, producing various non-pharmaceutical industrial psychotropic materials,

3) Keeping, carrying, purchasing, distributing, hiding, transiting, supplying and sailing narcotic drugs or non-pharmaceutical industrial psychotropic materials,

4) To establish or manage a place for the use of the narcotic drugs or non-pharmaceutical industrial psychotropic materials,

5) The use of the narcotic drugs or the non-pharmaceutical industrial psychotropic materials in any form and manner, unless it has been expected by the law.

6) Production, make, purchase, sale, keeping the equipment and tools related to make and use of non-pharmaceutical industrial psychotropic materials,

7) To scare away or giving shelter defendants, drugs or non-pharmaceutical industrial-psychotropic materials' offenders who have been prosecuted or arrested.

8) Erasing or hiding the crime evidences,

9) Placing drugs or non-pharmaceutical industrial-psychotropic materials or devices of their use in a place and accusing others,

Note 1-Narcotic drug in this law includes all the materials that will be manifested in the canon about the list of the narcotic drugs and its subsequent amendments that were approved by the Ministry of Health and Medical Education as the narcotic drugs in 2009.

Note 2-The Non-pharmaceutical industrial psychotropic materials offenses are followed by the provisions of the narcotic drugs law Proceedings.

Article 2-Anyone who cultivates the poppy or coca bush or cannabis for the production of non-pharmaceutical industrial psychotropic materials, in addition the annihilation of the crops he/she shall be punishable in terms of the amount of the cultivation as follows:

First time, 10 - 100 million Rials (currency of Iran),

Second time, 50 - 500 million Rials (currency of Iran), and 30 - 70 lashes,

Third time 100 million to one billion Rials, and 1 - 70 lashes and imprisonment for two time of five years,

Fourth time, Execution.

Note-If it is proved that the cultivation of poppy or coca bush or cannabis has been carried out on the order of the owner or tenant of the property or his lawyer, the person was sentenced who ordered it, provided the cause is more responsible than principal, and he/she will be sentenced by the punishments of this article, and the perpetrator who is the responsible for the cultivation will be sentenced to 10 - 30 million Rials in cash and 15 - 40 lashes. 
Article 3-Everyone who holds, hides or carries the seed or the poppy bush or the seed or leaf of the coca bush or the cannabis seed will be sentenced to $1-300$ million Rials in cash and 1 - 70 lashes, in the case of cannabis seed, the production intention of the narcotic or psychotropic drugs should be identified from it.

Article 4-If any bangs, hemps, grasses, opium, opium saps, burnt and scum or other drugs and non-pharmaceutical industrial psychotropic materials of the approved list of the Islamic Consultative Assembly are imported into the country or exported from it or these materials are produced, distributed or sold by anyone, the offenders are sentenced in terms of the amount of the mentioned materials as follows:

1) Up to 50 grams, 4 million Rials in cash and up to fifty lashes,

2) More than 50 grams up to 500 grams, 4 - 50 million Rials in cash, and 20 74 lashes, and if the court considers it can be three years imprisonment.

3) More than 500 grams up to 5 kilograms, 50 - 200 million Rials in cash and 50 - 74 lashes and three to fifteen years imprisonment,

4) More than 5 kilograms, execution and confiscation of property obtained from the same crime,

Note-If the perpetrators of the offenses referred to in paragraph 44 of this article have committed the crime for the first time and fail to distribute or sell them, and the material is twenty kilograms or less, the court shall be sentenced him/her to life imprisonment and seventy-four lashes and also confiscation of property obtained by the same crime with considering all the mentioned conditions.

5) More than 20 - 100 kilograms, in addition to the penalty provided in clause 4, for each kilogram, two million Rials shall be added to the cash penalty of the perpetrator, and in case of repeating the mentioned crime, the sentence is the execution and confiscation of property obtained from the same crime,

6) More than one hundred kilograms, in addition to punishing the cash penalty and lashes stipulated in the clauses 4 and 5, also the life imprisonment, and in the case reaping this crime, the sentence is the execution and confiscation of property obtained from the same crime.

Note-the perpetrators of the above offenses, if they have been acted as a chain form and the drugs have been for consumption personality, it will be subject to the penalties provided in Article 4, and if none of the two conditions are available, they will be sentenced to the punishment of this article.

\section{Reasons for Prohibiting Then Arcotic Drugs Use in the Book}

Using the sources of jurisprudence sources (Tradition book of the wisdom assembly), the prohibition of drug use is:

They ask you about wine and gambling, say: "They are a great sin and a benefit to the people, but their sin is more than their benefits".

Khamr (Wine) refers to any intoxicating substance: because Khamr in the word means covering, all the drunk people cause to cover and lose the wisdom 
and prevent recognizing good and bad by the human being, "Esam" (an Arabic word) also Means the sin, a state that causes a person to be deprived from gaining spend in the way of Allah and brings brutality and harm to man, and this prevents him from reaching the main purpose and the main purpose of creation, that is, human perfections and it inflicts greatly to the body and soul.

According to the respectable verse, alcoholic drinks and narcotic drugs, due to their many harms, cause the dementia of the human mind and his/her perception and understanding, and the false and temporary lusts are dominated on the individual and social human behaviors, therefore they are forbidden.

\section{The murder verse:}

NisaSura-Verse 29:

O you who have believed, do not consume one another's wealth unjustly but only [in lawful] business by mutual consent. And do not kill yourselves [or one another]. Indeed, Allah is to you ever Merciful.

According to the verse, any aggression, fraud, deceit, usury transactions, transactions whose limits are wholly unclear, and the purchase and sale of goods that do not have the rational advantage, the purchase and sale of corruption and sin goods and instruments, all mentioned issues are under of this general rule, and if, in various narratives, the word of :Void" has been interpreted to gambling, usury, and the like, in fact, that it is a clear example of the word and it is not unique to them (Makarem Shirazi, 2007: p. 41).

According to the verse, SahebJavher (Mohammad Hassan Najafi) says:

The interpretation of the verse is that preserving the soul and removing the pressure and difficulty and providing comfort and avoiding from killing yourself is obligatory. Sheikh Alish says (A scholar of the Maliki's religion) in his religious statement:

The repeated use of narcotics leads to create a heat in the soul that turns into a severe and destructive disease, so it includes the God statement that you must not kill each other.

The content of these verses ( 1 and 2) has obligated the maintenance of the life healthy and it has also obligated that anyone should not place his/her life in the risks that lead to the murder, unless there is more important interest, such as jihad in the way of God and because the drug can harm the health and well-being and this has been documented in medical terms, its use is also forbidden.

"Those who follow the Messenger, the unlettered prophet, whom they find written in what they have of the Torah and the Gospel, who enjoins upon them what is right and forbids them what is wrong and makes lawful for them the good things and prohibits for them the evil and relieves them of their burden and the shackles which were upon them. So they who have believed in him, honored him, supported him and followed the light which was sent down with him-it is those who will be the successful" (Surah al Araf/157).

The jurists and scholars elicit the above verse that the content of his invitation is in harmony with sound nature. He knows permissible the good deeds and what the sound nature likes it, and he prohibits what that is evil and hateful to 
them. He is not like the claimants in such prophecy and a mission that their aim is to chain the people and exploiting them, he does not fasten people, but he removes the loads of them and releases the chains that are placed on their feet, hands and necks. Now this question is posed that which wise person can say that the narcotic drugs are part of the good deeds and permissible. Of course, narcotic drug is a part of the evil and it is prohibited, because the harms of it is obvious to everyone and keeps the people in the carriage of humiliation ${ }^{20}$.

"O you who have believed, indeed, intoxicants, gambling, [sacrificing on] stone alters [to other than Allah], and divining arrows are but defilement from the work of Satan, so avoid it that you may be successful-Satan only wants to cause between you animosity and hatred through intoxicants and gambling and to avert you from the remembrance of Allah and from prayer. So will you not desist?

Muslims' familiarity with Islamic orders and their intellectual readiness for eradication of this entered the big social mischief into the profundities of their entity led to the final order that was sent with complete explicitness and clear-cut expression so that even excuse seekers could not object to it. This is the Verse that is under discussion.

"And spend in the way of Allah and do not throw [yourselves] with your [own] hands into destruction [by refraining]. And do well; indeed, Allah loves the doers of good." (Al Baqarah/195)

The beginning of the above verse refers to spending in the way of Allah, but in the following, by speaking out the sentence: "do not throw [yourselves] with your [own] hands into destruction" it alerts people to the important warning. Therefore, drug addiction is one of the greatest examples of destruction and annihilation. Although this sentence is about the leave off "spend in the way of Allah" for the Islamic Jihad, but it has a broad and diverse concept that includes many other things, including: "Human beings have no right" to traverse dangerous roads without prediction (whether in terms of insecurity, or climatic factors, etc.) or eating a food that is poisonous with a strong probability.

Or even he must not enter in the Jihad without a plan and program, and in all of these cases, human must not endanger his/her life without any reasons and he/she is responsible for his/her life. In the modern society, that effects and disadvantages of the narcotic drugs have been scientifically proven, and in fact, its consumption is ingestion of dangerous poison that gradually enters the body and ultimately leads to destruction or severe harm and endangering the life of the human without any reasons, so it is generally prohibited and should be avoided and, according to the late Allameh Tabatabai statement, this verse refers to committing any act that causes the destruction of mankind ${ }^{21}$.

\section{Conclusions}

As prevalent phenomena, narcotic drugs have made many difficulties for hu-

${ }^{20}$ Makarem Shirazi, Tafsir Nemone-Print 2007-Da al-Ketab al-Islamiyah-Part 6, p. 470.

${ }^{21}$ Allameh Seyyed Mohammad Hossein Tabatabaei, Tafsir Al-Mizan-Publishing Jame Masters of Qom, Vol. 1 p. 64. 
mankind and especially Muslims. Religious leaders have paid attention to them from the first appearances of Islam and have presented many appropriate and efficient solutions.

Islamic scholars and jurisconsults have used religious sources such as Quran, tradition, wisdom, and consensus that have formed the foundations of prohibition of narcotic drugs. According to these foundations, narcotic drugs are prohibited and forbidden in Islam due to harms and corruptions that they make for wisdom, body, family, society, state and government. The law stipulates religious punishments and worldly and legal sentences. Jurisconsults of the Islamic world who have been the main keepers of intellectual and ideological borders and they have a consensus about it and believe that narcotic drugs are certainly prohibited and no Muslim is allowed and permitted to use them. If anyone of Muslim uses it, he or she commits a great sin and should be punished.

\section{Conflicts of Interest}

The authors declare no conflicts of interest regarding the publication of this paper.

\section{References}

Abo Albarakat, I. A. A. (1985). Alsharh Al-saghir Ala Aghrab Al-masalekkela Mazhab Al-emam Malek (2nd ed.). (In Arabic)

Abrakrambi, N. A. (1997). Dictionary of Sociology (Hassan Pouyan Trans.). Tehran: Chapash Publications.

Ahmadi, M, A. (1998). Makatib Al-rasoul (PBUH) (Vol. 1). Qom Printing: First. (In Arabic)

Anas Ibn, M. A. (PBUH) (1998). Dar Al-Hadith Cultural Institute (p. 82). Publishing Organization. (In Arabic).

Ansari, S. M. (1988). Almakaseb (2nd ed., p. 78). Qom: Allameh Publications. (In Arabic)

Arian Pour, A., \& Manochehr (1988). Abridged Dictionary (English-Persian). Tehran: Amir Kabir.

Bojnourdi Mousavi, S. M. (2000). Beirout: Dar Al-fekr. Bita. (In Arabic)

Fedaei, F., \& Sajadieh, M. (1986). Recognition, Prevention and Treatment of Addiction (p. 9). Tehran: Tamyaz.

Hagh Panah, J. (1998). Article on the Trafficking the Narcotics and its Impact on the National Security of Iran (p. 18).

Ibn Baraj, A. (1985). Al-mahzab, Bicha. Qom: Islamic Publications Institute. (In Arabic)

Ibn Manzoor, A. F. (1986). Lesan Al-arab (2nd ed.). Beirout: Dar Al-tebahva Al-nashr, Bita. (In Arabic)

Ibn Shubeh, H. I. A. (1984). Toaf Al-oghol (2nd ed.). (In Arabic)

Isfahani (Fazel Hendi), Baha, Al-din Mohammad Ibn Al-hassan Ibn M. (1984). Kashf Al-sam (2nd ed.). (In Arabic)

Jafari, L., \& Mohammad, J. (1991). Legal Schools of Thoughts in Islam (2nd ed.). Tehran: Ganj Danesh. 
Karim Pour, S. (1985). Psychology of Addiction. Tehran: Amir Kabir Institute Publications.

Koleini, M. Y. (1986). Alkafi (T-Aleslamieh) (4th ed.). Tehran. (In Arabic)

Makarem Shirazi, N. (2007). Tafsir-e-Nemoneh, Dar al-Ketab al-Eslamiyeh.

Miller, R. L. (2014). Encyclopedia of Addictive Medicines (Ashkan Pashangzadeh, Trans.). Tehran: Jahad Daneshgahi, Publication Organization.

Mohammad al-Zahiri \& Al-Ghamrawi (1988). Al-Seraj-al-Vahaj, Sharh Ala Matn Menhaj al-Nuvayi, Vol. 1.

Moussa, H. Y., \& Saidi, A. F. (1989). Al-fesah fi Fegh Al-logha (p. 482). Qom: Office for Islamic Propaganda Publications.

Najafi, M. H. (Known as Saheb Al-javaher) (2000). Javaher Al-kalam fi Sobah (Vol. 7, p. 3).

Noori, H. I. M. T. (1987). Mostadrek Al-vasael in 18 Volumes (p. 78). Beirout: Ale Beit Institute.

Oakeley, S., \& Wayburn, E. (1972). Medicine California.

Shariati, S. (2006). A Study on Philosophy \& Realism (Vol. 4, p. 72).

Website of Students and University Graduates of Iranian Turkemans, Revised on November 4 (2007). 